Жукова Анастасия Евгеньевна

аспирант кафедры государственного

(конституционного) права

Южного федерального университета

\section{К ВОПРОСУ О СОВРЕМЕННЫХ КОНСТИТУЦИОННО-ПРАВОВЫХ ПРОБЛЕМАХ ЗАКРЕПЛЕНИЯ ПРЕДМЕТОВ ВЕДЕНИЯ И ОСУЩЕСТВЛЕНИЯ ПОЛНОМОЧИЙ СУБЪЕКТОВ РОССИЙСКОЙ ФЕДЕРАЦИИ (НА ПРИМЕРЕ РОСТОВСКОЙ ОБЛАСТИ)}

Zhukova Anastasiia Evgenyevna

PhD student, Public (Constitutional) Law Department, Southern Federal University

\section{CONCERNING THE CURRENT CONSTITUTIONAL AND LEGAL PROBLEMS OF ASSIGNMENT AND EXECUTION OF POWERS BY CONSTITUENT ENTITIES OF THE RUSSIAN FEDERATION (CASE STUDY OF ROSTOV REGION)}

\section{Аннотация:}

Статья посвящена анализу проблемы исключительных полномочий субъектов Российской Федерации на примере Ростовской области. Дается развернутая конституционно-правовая характеристика источников юридического закрепления полномочий субъекта Федерации в системе российского федерализма. Также анализируются проблемные вопросы разграничения полномочий 8 сфере осуществления публичной власти: между Федерацией и ее субъектами, между субъектом Федерации и местным самоуправлением.

Ключевые слова

конституционное право, федерализм, субъект Федерации, Ростовская область.
Summary:

The article deals with the exclusive powers of constituent entities of the Russian Federation by case study of the Rostov region. The author presents detailed constitutional and legal description of the sources of legal assignment of powers to a federal region in the system of Russian federalism. The paper also analyses problematic issues of division of powers in the sphere of public authority: between federation and its constituent entities, between constituent entity and local government.

Keywords: constitutional law, federalism, constituent entities of the Russian Federation, Rostov region.

Важную роль в федеративном государстве играет конституционно-правовая регламентация вопросов федеративного устройства, разграничения предметов ведения и полномочий между федеральным центром и субъектами, установления конституционно-правового статуса субъекта Федерации и гарантирования самостоятельного решения проблем, отнесенных к его исключительной компетенции. Не менее значимо устранение препятствий в сфере конституционно-правовой регламентации разграничения полномочий федеральной и региональной власти и еще одного уровня публичной власти - местного самоуправления. Отдельной проблемой конституционной теории и практики в нашей стране является соотношение конституционного термина «вопросы местного значения», полномочиями на решение которых наделены органы местного самоуправления, и категории «предметы ведения», относящиеся к компетенции Федерации и ее субъектов.

Конституция РФ 1993 г. принципиальным образом повлияла на государственное устройство, характер и структуру Федерации, а также содержание конституционно-правового статуса ее субъектов [1]. Конституционные нормы, закрепляющие основные положения федерализма, являются правовой основой теоретического анализа конституционно-правого статуса субъектов РФ. Строгий формально-юридический анализ конституционных положений указывает на то, что Конституция предполагает возможность разграничения предметов ведения между Федерацией и ее субъектами только на базе норм Конституции и в рамках договоров между Федерацией и субъектами. Можно согласиться с мнением, что это фактически исключает из перечня источников конституционно-правового регулирования разграничения полномочий конституционные и федеральные законы, а также конституции и уставы субъектов РФ [2]. Тем не менее именно в рамках федеральных конституционных и федеральных законов, конституций (уставов) субъектов происходит разграничение предметов ведения и исходя из их содержания определяется перечень предметов исключительного ведения субъектов.

Как обоснованно указывал В.М. Платонов, «в Российской Федерации не существует законодательно определенного перечня предметов исключительного ведения субъектов Российской Федерации» [3]. Предметы ведения субъектов определяются исходя из нормы ст. 73 Конституции РФ и сложившейся практики закрепления предметов ведения субъектов в их конституциях (уставах), которые не всегда соответствуют действующей Конституции. Возникающие противоречия разрешаются Конституционным судом РФ. 
Определение перечня предметов ведения субъекта Федерации «по остаточному принципу» в действующей Конституции России было адекватно существующим реалиям государственного строительства на момент принятия акта: наличию Федеративного договора и договоров о разграничении полномочий. Полагаем, что конкретизация предметов ведения субъекта возможна и необходима в рамках конституционной модернизации положений ст. 73 Конституции.

Думается, что возможность установления перечня предметов ведения субъектов Федерации в виде принятия федерального закона или предложенного в свое время Федеративного кодекса [4] вступает в противоречие с сущностью федеративного государства (имеющего черты либо договорной федерации, либо конституционной). Этот подход придает системе федеративных отношений характерные черты унитарного государства, например определение компетенции региональных органов власти императивно «сверху» без участия субъектов Федерации. Данный подход наделяет их характеристиками автономных образований децентрализованных унитарных или регионалистских (региональных) государств.

Таким образом, наиболее адекватны существующему федеративному устройству закрепление в ст. 73 Конституции России закрытого перечня предметов исключительного ведения субъектов, указание на разграничение сфер исключительной компетенции субъекта и местного самоуправления. Следовательно, дальнейшее совершенствование федерального законодательства, касающегося предметов исключительного ведения субъектов РФ, должно осуществляться прежде всего в рамках принятия закона о поправке к Конституции «О предметах ведения субъекта Российской Федерации», вносящего изменения в текст ст. 73.

Несмотря на то что федеральное законодательство нуждается в трансформации, немало доступных сегодня возможностей совершенствования реализации полномочий субъекта не используются самими субъектами. Рассмотрим направления улучшения регионального законодательства на примере Ростовской области.

В системе источников закрепления полномочий Ростовской области на региональном уровне важнейшим элементом является Устав Ростовской области. О разграничении предметов ведения между Российской Федерацией и рассматриваемой территорией говорится в ст. 6 и 7 этого документа [5]. Полагаем, что в настоящее время областными законотворцами не реализованы многие важнейшие правотворческие возможности, способные повлиять на содержание конституционно-правового статуса области. Так, на сегодняшний день в Ростовской области не учрежден уставной (конституционный) суд.

Эта проблема характерна не только для Ростовской области, но и для большинства субъектов Российской Федерации. Сейчас в них действуют 17 конституционных (уставных) судов, причем деятельность Конституционного суда Республики Бурятия приостановлена с 2013 г. [6]. Стимулирование субъектов к решению данного вопроса возможно путем организации внеочередных судебных органов либо временной реализации Конституционным судом РФ функций органов конституционной юстиции субъектов. Предлагаем на уровне федерального законодательства закрепить за конституционными (уставными) судами субъектов Федерации полномочия на осуществление как предварительного, так и последующего нормоконтроля законодательства субъекта. Для этого необходимо внесение соответствующих изменений в федеральный конституционный закон «О судебной системе Российской Федерации», предусматривающих закрепление полномочия органов конституционного (уставного) правосудия в предварительном порядке оценивать проекты законодательных актов субъектов РФ.

Таким образом, можно сделать следующие выводы. Несмотря на четверть века развития нашей страны как федеративного государства, вопросы федеративного устройства, в частности исключительного ведения субъектов Федерации, продолжают находиться в проблемном поле российского конституционализма. Вопрос законодательного закрепления перечня предметов исключительного ведения субъектов должен быть окончательно решен внесением поправок в ст. 73 Конституции России. Этот путь в наибольшей степени соответствует федеративному государству. Кроме того, необходимо стимулирование субъектов к созданию конституционных (уставных) судов путем как расширения перечня их полномочий, так и осуществления нормоконтроля за региональным законодательством Конституционным судом РФ в тех регионах, где данные органы отсутствуют.

\section{Ссылки:}

1. Конституция Российской Федерации : принята всенародным голосованием 12 дек. 1993 г. : с учетом поправок, внесенных законами РФ о поправках к Конституции РФ от 30 дек. 2008 г. № 6-ФКЗ, 30 дек. 2008 г. № 7-ФКЗ, 5 февр. 2014 г. № 2-ФКЗ, 21 июля 2014 г. № 11-ФКЗ // С3 РФ. 2014. № 31. Ст. 4398.

2. Гончаров Ю.В. Некоторые проблемы разграничения полномочий между Российской Федерацией и Ставропольским краем // Закон и право. 2009. № 11.

3. Платонов В.М. Региональное правотворчество по вопросам исключительного ведения субъектов Федерации // Право и жизнь. 2009. № 10. 
4. См.: О Плане законодательных инициатив Совета Федерации Федерального собрания Российской Федерации на первое полугодие 1997 г. [Электронный ресурс] : постановление Совета Федерации Федерального собрания Российской Федерации от 23 янв. 1997 г. № 4-СФ. URL: http://www.pravo.gov.ru/proxy/ips/?docbody $=\&$ link $i d=0 \&$ nd $=102045344 \& b p a=c d 00000 \& b p a s=c d 00000 \&$ intel-

search=\%F2\%F0\%F3\%E4\%EE\%E2\%EE\%E9+\%EA\%EE\%E4\%E5\%EA\%F1 (дата обращения: 10.01.2017).

5. Устав Ростовской области [Электронный ресурс] ; действующая редакция с изм. от 28 дек. 2015 г. URL: http://www.donland.ru/documents/Ustav-Rostovskojj-oblasti?pageid=128483\&mid=134977\&itemld=19328 (дата обращения: 12.12.2016).

6. Действующие Конституционные (уставные) суды субъектов Российской Федерации [Электронный ресурс]. Доступ из справ.-правовой системы «Гарант».

\section{References:}

Goncharov, YuV 2009, 'Several problems of delineation of authority between the Russian Federation and the Stavropol Territory', Zakon i parvo, no. 11, (in Russian).

Platonov, VM 2009, 'Regional lawmaking concerning exclusive competence of the constituent entities of the Russian Federation', Pravo i zhizn', no. 10, (in Russian). 